\title{
The political ecology of seed security in the Northern Ghanaian Savannahs
}

\author{
Michael Biwalib Madin
}

Accepted: 8 November 2020/Published online: 19 November 2020

(C) Springer Nature B.V. 2020

\begin{abstract}
Seed security is being promoted as a means of achieving productivity, food security, and resilience among smallholders. This has resulted in notions that vulnerabilities among smallholders in Africa are the outcomes of inadequate adoption of improved seeds. What these perspectives have neglected is: How politics mediate access to seeds? and Whether and how politics influence farmers' perception of seed security? This study draws upon a case study of Northern Ghanaian Savannahs to examine politics and seed security among smallholders. The logistic analysis shows that the presence of recurring conflicts significantly determines how farmers perceived vulnerability to seed insecurity. Thus, farmers from relatively peaceful villages were 4.705 times more likely to rate themselves as not vulnerable to seed insecurity compared to their counterparts experiencing recurring conflicts. Analysis further shows that smallholder vulnerabilities to seed insecurity are constructed at the intersection of historical ethnic conflicts and neoliberal policies in ways that contest the dominant narratives. Key for achieving seed security is a better understanding of how local and macro politics influence perceptions and mediate access to healthy and desirable seeds.
\end{abstract}

M. B. Madin ( $\square)$

Department of Geography and the Environment, University of Denver, 2199 S. University Blvd., Denver, CO 80208, USA

e-mail: michael.madin@du.edu
Keywords Politics - Seed security - Seeds · Smallholders · Northern Ghanaian Savannahs

\section{Introduction}

For the past two decades, the Food and Agriculture Organization [FAO] has supported efforts toward ensuring adequate access to healthy and desired seeds of all crops among smallholder farmers, particularly in the developing world, under the concept of seed security (FAO 1998, 2005; Sperling et al. 2008). The efforts to achieving seed security are deemed necessary because seed systems serve as an important facet for building farmers' resilience-given that access to desired seeds has direct links to food security and resilient livelihoods (FAO 2010; Coomes et al. 2015; Kansiime and Mastenbroek 2016). However, evidence shows that smallholders in Africa are less likely to adopt improved seed varieties relative to other parts of the Global South (see Byerlee and Bernstein 2013; Gaffney et al. 2016). This situation has received recent scholarly attention toward understanding factors underlining this phenomenon in Africa. Yet, these studies tend to be less historicized and politicized and often ignore how power relations interact with environmental considerations to influence farmers' decisions to adopt quality seeds (e.g., Mucioki et al. 2016, 2018; Gaffney et al. 2016). 
It is also commonly argued, for example, that seed insecurity and vulnerability among smallholders in Africa are the results of inadequate adoption of improved seeds and modern techniques of farming (Mucioki et al. 2018; Gaffney et al. 2016; Kansiime and Mastenbroek 2016;). Besides, these approaches generally assert that seed security-determined by the adoption of certified seeds-can result in all-win outcomes where food security can be achieved alongside climate adaptation (see The Wall Street Journal 2016; Coomes et al. 2015; McGuire and Sperling, 2011). Linked to this is the prioritization of genetically modified seeds as climate-smart to the neglect of the indigenous seed system in case studies (See Rock 2019; Waldman et al. 2017; Gaffney et al. 2016; Nyantakyi-Frimpong and Bezner-Kerr 2015).

These apolitical approaches still dominate despite earlier calls for seed security to be situated in the political and historical context within which the farmers operate (McGuire and Sperling 2013; Sperling 2008). Moreover, Robbins (2012) showed that environmental issues become a product of social and political processes when local groups (e.g., defined by ethnicity) secure control over collective resources at the expense of others by leveraging management interventions through state or private agents. Similarly, existing historical constructs and protracted ethnic conflicts within and between communities become "ecologized" through hindering or changing seed intervention policy (McGuire and Sperling, 2013; Sperling 2008; Taylor 2007; Talton 2003b). In response to the above, this paper deconstructs the embedded [socio]-ecological and political issues using political ecology to identify broader issues aside proximate factors. In the quantitative analysis, I hypothesized that besides the socio-demographics and wealth, political drivers (i.e., ethnic conflicts) are major determinants of farmers' seed security. To test this, all the independent variables were included while using the stepwise method to retain only those that met Wald's ratio significance $(p<10 \%)$. For the qualitative aspect, excepts of participants' narratives are illustrated to show how vulnerabilities to seed insecurity are constructed at the intersection of historical ethnic conflicts, political, and neoliberal economic policies.

Thus, this study offer an example of how smallholder vulnerabilities to seed insecurity are constructed at the intersection of historical ethnic conflicts, political, and neoliberal economic policies in ways that contest the dominant narratives of seed security. It draws empirical evidence from fieldwork conducted from June to August 2019 in the Northern Ghanaian Savannahs (NGS), an agroecological region characterized by recurring ethnic conflicts and policy neglect.

\section{Theoretical framework}

Several approaches for studying seed security have been employed in research (Mucioki et al. 2018; Kansiime and Mastenbroek 2016; McGuire and Sperling 2013). The dominant studies have generally focused on farmers' demographics and household wealth in explaining the vulnerability and adaptation of certified seeds (see Mucioki et al. 2018; Gaffney et al. 2016; Mucioki et al. 2016; Violon et al. 2016; Wencélius et al. 2016). Others have focused on the socio-ecological factors influencing farmers' seed networks (Coomes et al. 2015; Ricciardi 2015). However, most farmers in sub-Saharan Africa and other parts of the Global South are often faced with challenges acquiring healthy viable seed of preferred varieties due to conflicts, inappropriate seed aid interventions, and neoliberal policies. (Wattnem 2016; McGuire et al. 2015; Sperling 2008). Implying that farmers' seed security is also determined by the political-economic environmental context within which they operate.

As such, this study adopts a political-ecological framework to assess seed security in the NGS. The political aspect focuses on how neoliberal policies, government seed programs, and ethnic conflicts impact access to and adoption of seeds among farmers (Shiva et al. 1999; Sperling et al. 2008; Rock 2019). The [socio]-ecological perspective focuses on understanding the dynamic interrelations among microlevel decision-making, and cultural contexts of human-environment relations and seed security (Wattnem 2016; Nyantakyi-frimpong and Kerr 2015; McGuire and Sperling 2013; Sperling 2008). Seed security assessment refers to a method of evaluation to help ascertain the state of seed systems (normal or during crises) and highlights specific factors that foster or undermine resilience (Sperling 2008). This helps appraise seed security with regards to seed availability, access, quality, and varietal suitability (FAO 
2016). The research adds to these factors by contending that we need to understand how the intersection of historical conflicts, political, and neoliberal economic policies shape seed security. To do this, the paper first reviews the past ambits of the political-economic context of the NGS.

\section{Literature review}

\section{A brief political-economic context of the Northern Ghanaian Savannahs}

The economic and livelihood activities in the NGS are predominantly agriculture-based (Nyantakyi-Frimpong and Bezner-kerr 2015; Ghana Statistical Service 2012). For example, the Ghana Statistical Service (2012) indicated that while only $41.5 \%$ of the national economic active population is engaged in agriculture activities, the regions constituting the NGS far exceed the national average. Specifically, the report shows that $73.1 \%$ of the economic active population in the Northern region, $71.8 \%$ in Upper West, and $68.9 \%$ in Upper East are employed in the agricultural sector. Besides, agricultural practice in these regions is mainly smallholder farming systems and cultivation of food crops (Al-hassan and Poulton 2009; Chamberlin 2007; Ghana Statistical Service 2014c; Shepherd et al. 2005). These serve as major reasons underlining why farmers in this zone have historically received much lower inflows of state funding, and participated much less in trading activities compared to the south (Al-hassan and Poulton 2009; Shepherd et al. 2005). The other main factor is the liberalization of the economy, which favored the export crops of the southern farmers engaged in cash cropping (Nyantakyi-frimpong and Bezner-Kerr 2015; Plange 1979).

Whereas the British established colonial rule in 1874 and brought the Northern Territories (i.e., NGS) under colonial rule in 1902, it was later in 1949 when the colonial government made the first attempt to support agriculture in NGS (Nyantakyi-frimpong and Bezner-Kerr 2015; Asuming-Brempong 1994). Representing 37 years under government control without funding and development policy support to the agriculture sector. According to Asuming-Brempong (2003), the 1949 program was the first countrywide attempt to promote high-input agriculture practices among food crop farmers in the NGS. The immediate post-independence government also initiated other countrywide approaches to enhance the 'modernization' of agriculture, after realizing that the previous program had accumulated high debts with few intended impacts (Hilton 1959). For general and detail historical government agriculture sector interventions, see Nyantakyi-frimpong and Bezner-Kerr (2015); Asuming-Brempong (2003); and Plange (1979). Hereafter, the paper focuses on government seed programs and interventions toward providing improved seeds to farmers.

\section{A brief overview of seed programs in Ghana}

In 1958, the Hybrid Maize Production Unit was established as a commercial entity to produce improved maize varieties, and was renamed the Seed Multiplication Unit (SMU) in 1961 when it moved from the production of hybrid seed to open-pollinated varieties (Lyon and Afikorah-Danquah 1998). The Plant Quarantine Act of 1965 and the National Redemption Council Decree 100 of 1972 were also enacted in this period to regulate seed production in Ghana (Alhassan and Bissi 2006). The SMU started a contract growers' scheme after these legal regimes, although it continued to produce basic seed on its own farms (Delimini and Wobil 1998). The duties of seed multiplication were transferred to the Ghana Seed Company (GSC), a semi-autonomous parastatal body in 1979 (Lyon and Afikorah-Danquah 1998). However, the GCS suffered losses over the years because of low output, overstaffing, high capital investment, low seed quality, and poor marketing strategy (BockariKugbei 1994). The Ghana Seed Company was established in 1979 to produce and market improved seeds to farmers (Tripp and Mensah-bonsu 2013). In 1980, the government initiated the Northern Region Rural Integrated Project with a funding partnership from the Canadian International Development Agency, with a component intended to provide improved seeds to smallholder farmers (Seini and Nyanteng 2003). But this intervention could not be sustained beyond the end of the external funding in 1989 (Botchway 2001). Moreover, Ghana's Structural Adjustment Program (SAP) and its conditionalities in 1983 resulted in government withdrawal of subsidies and support to the farmers (Nyantakyi-frimpong and Bezner-Kerr 2015; Shepherd et al. 2005). The GSC was also privatized as 
part of the SAP economic recovery program (Lyon and Afikorah-Danquah 1998).

The number of private seed growers, mostly operating as small-scale entities, has risen significantly in the country after the SAP implementation (Lyon and Afikorah-Danquah 1998). The role of the state has also become supportive and regulatory, restricted to policy formation, research, breeder and foundation seed production, quality control, and training (Delimini and Wobil 1998). Amidst the impacts of the SAP, the Sasakawa-Global 2000 program with government support was introduced in 1986 to encourage farmers to plant improved seed varieties (Al-hassan and Poulton 2009). However, the program failed and was abolished based on several reasons including poor debt recovery and narrow coverage of a few staple crops (Al-hassan and Poulton 2009; Nyantakyi-frimpong and Kerr 2015). Following the SAP deregulatory conditionalities, the private sector and international development partners have initiated and funded various initiatives to improve access to certified seeds nationwide (Tripp and Mensah-bonsu 2013; Lyon and Afikorah-Danquah 1998). These include GTZ West African Seed Network, USAID-funded West Africa Seed Alliance, USfunded Millennium Development Authority, USAIDADVANCE, African Development Bank, and Japan International Cooperation Agency.

Currently, the Alliance for a Green Revolution in Africa (AGRA) is the most prominent donor in the seed sector. AGRA has been active since 2007, providing grants and support for small private seed companies and funding plant breeding in Ghana (Tripp and Mensah-bonsu 2013). This follows the laying of the Plant Breeders Bill in Parliament to pass a law that would grant intellectual property rights to plant breeders of new and novel varieties (Rock 2019). More recently, the government launched a flagship agricultural program dubbed Planting for Food and Jobs (PF\&J) on April 19, 2017 (MOFA 2017). The flagship program is implemented through a partnership with AGRA and the private sector. The core target of the initiative is to revamp the declining growth in the agriculture sector to achieve food security and reduce the level of food importation (Tanko et al. 2019). One of the key pillars of the PF\&J is to supply subsidized (with a 50\% reduction in cost) certified seeds and fertilizers to farmers. In the result section, I utilize a case study of the PF\&J initiative to investigate whether and how the state effort to supply improved seeds to farmers foster seed security in an ecological zone characterized by resource struggle.

Ethnic conflicts, resource struggle, and vulnerability to seed insecurity

From the 1980s to the present, a series of conflicts has engulfed almost all parts of the Northern half of Ghana (Debrah et al. 2016; Talton 2003b). In most of the disputes, historically non-centralized, politically and resource marginal groups have engaged in protracted fighting with one or several of their historically centralized and dominant neighbors ( $\mathrm{Pul}$ 2004; Talton 2003a, 2010; Tonah 2012). According to Talton (2003a), the antagonism that became characteristic of the relationship between ethnic groups of the NGS took root in the postcolonial period and was a product of the political structure that the colonial officers imposed. The key underlining factor being the British indirect rule, which was developed around tribe and chieftaincy. For instance, under the 1932 ordinances, centralized ethnic groups' control over the noncentralized groups became enforceable by colonial law, making it illegal for non-centralized groups to refuse to respond to centralized groups summons or demands for tribute (Talton 2010). Thus, centralized groups whose system of authority satisfied the British approach towards governance were recognized as politically legitimate, while those that did not were largely disenfranchised and forced under the political jurisdiction of the recognized groups, despite little historical precedent for such a relationship (Pul 2004; Talton 2003a, 2010; Tonah 2012). The recognizing of the political status of only centralized groups in strict terms fostered the development of politicized ethnic identities and symbols that became associated with resources (e.g., farmlands and water bodies), which stimulated ethnic competition for political and natural resources.

This political inequality in NGS and tension between ethnic groups persisted under postcolonial regimes and led to more protracted violence from 1980 up to the present day. It has been argued that recent conflicts are reported to be mainly fueled by the struggle for resources (e.g., farmlands), power and supremacy, and the rejection of these requests by groups regarded as powerful and superior (Debrah et al. 2016; Mahama and Longi 2013; Talton 
2003a, 2010). A good example of ethnic-exacerbated land dispute conflict was triggered in May 2018 in Naduni, Chereponi District (Internal Displacement Monitoring Center, 2019), which resulted in violent clashes, loss of lives, destruction of farms and seeds, and soured relationships among ethnic groups (Mahama and Longi 2013). As such, vulnerabilities among smallholders in NGS are reported to have been intensified by these protracted conflicts (Antwi-Agyei et al. 2012; Michalscheck et al. 2018; Musah-Surugu et al. 2018; Talton 2003b).

Studying the effects of conflict on natural resources (e.g., farmland and seeds) has become important in the NGS, where over $70 \%$ of the population is directly engaged in agriculture as smallholders for their daily survival (SRID 2016; Al-hassan and Poulton 2009; Shepherd et al. 2005). FAO et al. (2019) indicated that whereas hunger has increased in many countries, the greatest threats are in areas with conflicts. Vulnerable populations to the increasing climate extremes, particularly conflict-affected areas are also disproportionately challenged by both COVID-19 and the impact of containment measures-which has caused food and nutrition shortages and driven governments to reduce social services that are most critical to the marginalized (Development Intiatives 2020). Besides, ethnic conflicts in this part of Ghana have been reported to have adversely affected global disease eradication efforts (Hopkins et al. 2005). Likewise, FAO $(2010,2015)$ has indicated that human-induced disasters, such as ethnic conflicts, have had an increasingly devastating impact on farmers' access to quality seeds through halting crop production, destroying agricultural assets, and hindering access to agricultural inputs. Taylor (2007) argued that conflicts that restrict access to land and natural resources of these kinds, have significant effects on smallholder production systems, and require research to adequately inform interventions.

Similarly, Sperling (2008) indicated that in a prolonged conflict, farmers' social relationships are normally strained such that the routine networks of gift or exchange of seeds are markedly impeded. Samberg et al. (2013) found that conflicts weaken social ties within communities because of the fracturing effects of tensions and violent destructions, which increase the dependence of farmers on outside sources for seed. In most cases, formal seed sources are found to break down amidst conflict because the government and seed companies usually retrench from conflict areas (FAO 2016; McGuire and Sperling 2013; Sperling 2008; Sperling et al. 2008). Hence, farmers always experience seed insecurity amidst conflicts due to limited seed availability and accessibility (FAO 2016). Drawing upon McGuire and Sperling's (2013) and Sperling's (2008) seed security assessment among farmers (in East Africa and Haiti) in the contexts of political and civil conflicts coupled with climate change, this paper utilizes a case study of a village experiencing recurring conflicts and another with no recent conflicts to evaluate how the presence of repeated conflicts shape farmers' seed security.

\section{Methods}

Study locale and sampling design

Fieldwork for this study was conducted from July to August 2019 in two farming villages located $120 \mathrm{~km}$ apart (Fig. 1). The two villages were renamed Village $\mathrm{A}$ and Village B to ensure the anonymity of respondents. These villages were purposefully selected for comparative analysis. While both villages are similar based on farming practices, they differ based on sociopolitical characteristics (Table 1). Village A was selected due to vulnerability to climate risks, while Village B was selected because of climate risks and protracted ethnic conflict. Both villages are very remote and highly impoverished. Public transportation is limited and unreliable, with bicycles and motorcycles being the primary mode of transportation. The limited availability of transportation poses a significant challenge to accessing seeds outside the villages. In both villages, smallholder farming and livestock herding are the main livelihood activities. Farming is typically more oriented towards household consumption than for commercial purposes. The main staple crops include yam, maize, cassava, groundnut, beans, and millet. Households' livestock holdings include cattle, sheep, goats, chickens, and guinea fowl.

The two study sites fall within NGS agro-ecology, which is among the poorest parts of the country. The population living below the poverty line is above $65 \%$ (Amuzu et al. 2014). The annual mean temperature in this zone ranges between 20.9 and $35.4{ }^{\circ} \mathrm{C}$. The Savanah zone has a generally dry climate, marked with a single rainy season that begins in May and ends 


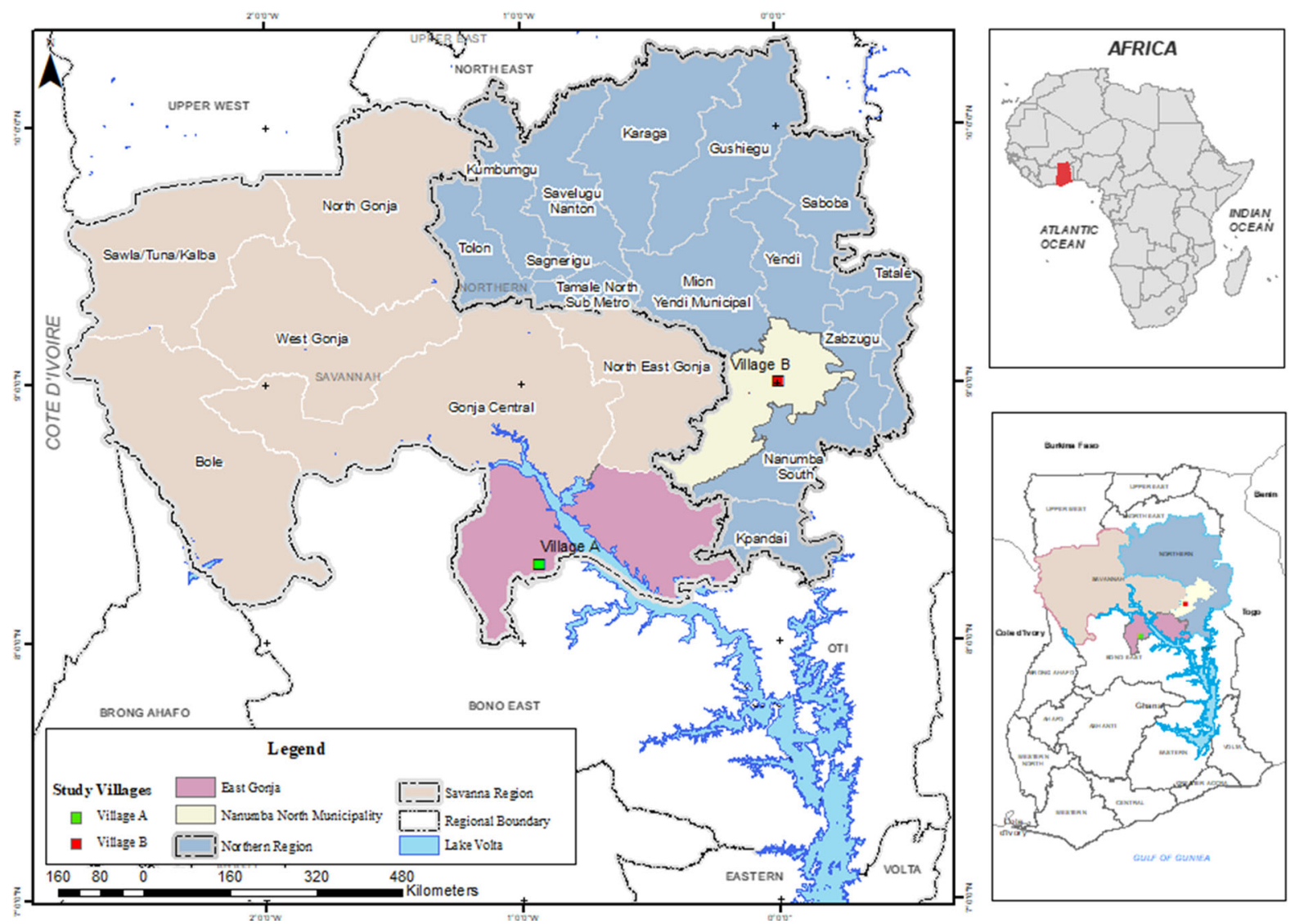

Fig. 1 Location of study villages in Nanumba North Municipality (NNM) and East Gonja Municipality. Source: Map drawn by Charles Asare Bamfo Jr, GIS Department, Ghana Statistical Service, Accra

in October. Total annual rainfall ranges between 631 and $1734 \mathrm{~mm}$. The zone is also the most susceptible to severe climatic variations, with persistent droughts, recurring floods, and frequent crop failures (Nyadzi et al. 2018; Antwi-Agyei et al. 2012). Limited attention and investment by the central government are argued to be exacerbating the region's vulnerability to climate change (Yaro et al. 2015; CARE International 2013; Asuming-Brempong 2003). These vulnerability contexts made NGS a suitable locale to study how ethnic conflicts and politics affects seed security.

The study adopted a mixed-methods approach using a convergent research design (Creswell and Clark 2017). A combination of quantitative and qualitative data collection techniques was used. Since there is no formal consensus on seed security in northern Ghana, a quantitative survey was needed to identify general patterns and statistical significance of those findings. The multi-faceted and contextual nature of seed security (FAO 2015) also required qualitative data collection to understand farmers' lived experiences. The study's data is derived from my thesis and has received research ethics approval from the University of Denver [IRB Protocol \# 1428173-1]. Data collection was implemented in two stages, as explained below.

A structured questionnaire was prepared and pretested in the field before the actual data collection. This questionnaire was designed following the FAO's seed security assessment guidelines (FAO 2015). Walking along village footpaths and streets, every third household was selected for the survey until the required sample size was obtained. A systematic random sample of 429 households was surveyed, with 189 in Village A and 240 in Village B surveyed in the first stage (Tables 1 and 2). Survey questions included household socio-economic characteristics, current 
Table 1 Characteristics of the two case study villages Source: Compiled from Ghana Statistical Service (2014a); Ghana Statistical Service (2014b); Field notes July to August 2019

\begin{tabular}{lll}
\hline Main points of comparison & Village A & Village B \\
\hline Total population & $2355^{*}$ & $5035^{*}$ \\
Total households $(\mathrm{HH})$ & $336^{\mathrm{a}}$ & $607^{\mathrm{b}}$ \\
Average HH size & $8.2(7.1)^{\mathrm{a}}$ & $7.7(8.2)^{\mathrm{b}}$ \\
Sampled households & & $\mathrm{n}(240)$ \\
Quantitative survey & $\mathrm{n}(189)$ & $\mathrm{n}(10)$ \\
Qualitative interviews & $\mathrm{n}(10)$ & $2.7 \%^{\mathrm{b}}$ \\
Population growth rate & $2.7 \%^{\mathrm{a}}$ & Konkomba, Dagomba \\
Main ethnic groups & Konkomba, Gonja & 2.35 (Ha) \\
Average farm size & $2.28($ Ha) & Protracted conflicts since the \\
Conflicts and political context & Conflict in 1992-but very & $1980 \mathrm{~s}$ \\
& peaceful now & 20 km (Bimbilla) \\
The nearest town with subsidized improved seeds & 24.5 km (Yeji) & Market available \\
supply & & No market-24.5 km to the nearest \\
Access to market & market & \\
\hline
\end{tabular}

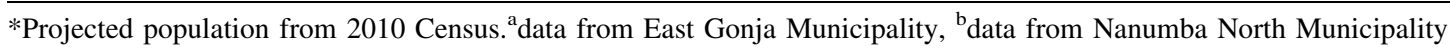

crops cultivated, and seed systems profile. There were additional questions on seed sources, indicators of seed security, farmer social networks, and experiences of ethnic conflicts on seed security. In the second stage of fieldwork, qualitative data collection was used to delve deeper into the nuances of seed insecurity experiences and perception amid conflicts. This stage of fieldwork involved conducting in-depth interviews and focus groups. Twenty in-depth interview participants were selected purposefully from the survey sample, using maximum variation sampling (Miles et al. 2014). Maximum variation was achieved by considering ethnic groups, crops cultivated, methods of farming, and gender. After the interviews, separate focus group discussions (FGDs) were organized. The FGDs were designed to elucidate gender-related issues around seed security. As part of this stage, secondary data were also collected from government institutions. The Agriculture Development Unit provided information on the supply of subsidized improved seeds.

Quantitative data analysis

The dependent variable was the households' rating of their vulnerability to seed insecurity amid conflicts. The response categories of the dependent variable included; (1) not vulnerable, (2) not sure, and (3) vulnerable to seed insecurity. The independent variables considered are illustrated in Table 2. These variables were selected based on FAO's seed security assessment framework (FAO 2015). The analytic sample was 429 farmers who rated their household's seed (in)security status based on their experience and perception amid conflicts. StataIC 16 and SPSS software were used in data analysis.

The analysis presented in Table 2 shows Chi-square and Cramer's V statistics for the binary relationship between the independent variables and dependent variables. Multinomial logistic regression was used to evaluate the combined relationships between the independent variables and dependent variable categories (see Table 4). Multinomial logistic regression was employed for the statistical analysis because of the categorical nature of the dependent variables (Field 2013, p. 2176). The multinomial logistic regression model is expressed as below. Where $\mathrm{Y}$ is the polytomous outcome variable with given categories (in this paper three categories i.e., $y_{1}, y_{2}$, and $\left.y_{3}\right)$. Let $y_{1}$ be the reference category, and $\mathrm{x}$ be the independent variable or the predictor variable. Where $\alpha$ is the intercept parameter, and $\beta$ is the regression coefficient corresponding to $\mathrm{x}$. 
Table 2 Descriptive statistics of the household survey $(n=429)$ Source: Compiled from Ghana Statistical Service (2014a); Ghana Statistical Service (2014b); and fieldwork, July to August 2019 a \& cdata from East Gonja Municipality, ${ }^{\mathrm{b}}$ data from Nanumba North Municipality, ${ }^{\mathrm{d}}$ only sampled households who acquired seeds

\begin{tabular}{ll}
\hline Characteristics & Survey \\
\hline Mean age of sampled household heads (years) & 40 \\
Average household members age within 18-60 & 4.1 \\
Average household members engaged in agriculture & 2.9 \\
Male headed households & $(93.5 \%)(89.2 \%)^{\mathrm{a}}(91.3 \%)^{\mathrm{b}}$ \\
Female headed households & $(6.5 \%)(10.8 \%)^{\mathrm{a}}(8.7 \%)^{\mathrm{b}}$ \\
Average farm size (Hectares) & 2.3 \\
The major cultivated crops & \\
Maize & $381(88.8 \%)$ \\
Yam & $373(86.9 \%)$ \\
Cassava & $211(49.2 \%)$ \\
Groundnut & $46(10.7 \%)$ \\
The method of land preparation & \\
Use of tractor & $135(31.5 \%)$ \\
Use of tractor and hand tools & $67(15.6 \%)$ \\
Use of hand tools only & $227(52.9 \%)$ \\
Households sources of income & \\
Sale of crop produce & $421(98.1 \%)$ \\
On-farm labor & $68(15.9 \%)$ \\
Sale of charcoal & $74(17.2 \%)$ \\
Sale of livestock & $113(26.3 \%)$ \\
Remittances & $51(11.9 \%)$ \\
Farmers who receive subsidized improved seeds under PF\&J & \\
2017 & \\
Males & $1070(98.7 \%)^{\mathrm{c}}$ \\
Females & $14(1.3 \%)^{\mathrm{c}}$ \\
2018 & \\
Males & $54(96.4 \%)^{\mathrm{c}}$ \\
Females & $2(3.6 \%)^{\mathrm{c}}$ \\
Means of household seeds acquisition & \\
Purchase with money & $214(73.3 \%)^{\mathrm{d}}$ \\
Barter & $7(2.4 \%)^{\mathrm{d}}$ \\
Gift & $3(1.0 \%)^{\mathrm{d}}$ \\
\hline & $68(23.3 \%)^{\mathrm{d}}$ \\
\hline
\end{tabular}

Qualitative data analysis

Qualitative data analysis followed the methods outlined by Miles et al. (2014), and Patton (2014). Handcoding was used to ensure deep and continued immersion in the qualitative data, including in-depth interviews and FGD transcripts. Firstly, a coding scheme was developed using key themes from the literature review. Key themes were identified according to criteria that included: (1) relevance to the research objectives; (2) frequency that the theme was 
mentioned; and (3) the predominance of the same theme across different types of participants (Miles et al. 2014; Patton 2014). In the results section, verbatim interview quotations have been included to give voice to respondents' own views. These quotations have been carefully selected based on the following criteria: the ability to represent divergent perspectives, typical views expressed by many respondents, and the depth or clarity with which the idea was conveyed (Miles et al. 2014; Patton 2014).

\section{Results}

Before moving into the analysis, Table 2 describes the socio-economic characteristics of the sampled household heads. The survey was conducted with 401 male heads and 28 female heads. For in-depth interviews, 14 males and 6 females were purposefully recruited. The mean age of the household heads recruited for indepth interviews was 40 years, with an age range of 30 to 84. Other characteristics of the respondents are illustrated in Table 2.

It is worth noting that the goal of this section is not entirely to provide empirical evidence on the exact impact of conflicts on smallholders' seed security in the NGS. For more empirical assessment of impacts of conflicts on smallholder seed security in sub-Saharan Africa, readers should see Sperling et al. (2008); McGuire and Sperling (2011); and McGuire and Sperling (2013). What this section seeks to do is to examine how farmers rate their seed security based on experiences and perceptions of ethnic conflicts and resource struggles. This is important because such insights shape and form a basis for adaptation strategies and define the success of policy interventions (Waldman et al. 2017; Jain et al. 2015; Sekhar et al. 2015).

Quantitative results of determinants of household seed insecurity during conflicts

The findings presented in Fig. 2 and Table 3 are revealing in several ways. First, it emerged that the gender of the household head is significantly related to seed (in)security rating amid conflicts. Female-headed households were more likely to rate themselves as seed secured amidst conflicts (see Fig. 2a). This result is explained by the type of crops cultivated and the extent of extra-village seeds acquisition by each gender. Male-headed households were found to be predominantly engaged in farming yams, whereas female-headed households tended to cultivate groundnuts. Yam seeds are bulky and costly to be transported home after harvest, and are usually stored on farms, which makes the seeds prone to destruction during conflicts (see Fig. 3). Besides, male-headed households resort to traveling more outwardly to neighboring communities than their female counterparts in accessing seeds during planting. Hence, the tendency to embark on this strategy becomes impossible during conflicts due to the curfews imposed by the government and fear of insecurity. This conforms with Samberg et al. (2013) and Sperling's (2008) finding that weakening social ties due to the fracturing effects of conflicts affect farmers' seed acquisition patterns.

The results further showed that households' seed security status depended significantly on the respondents' location. Thus, farmers in Village A rated themselves to be more seed secure than those in Village B amidst conflict stress. This finding corroborates with earlier findings that human-induced disasters, such as wars and ethnic conflicts, have had an increasingly devastating impact on seed security of the farmers within those areas (see FAO 2010, 2016; McGuire and Sperling 2013; Sperling 2008; Sperling et al. 2008). These findings are largely attributed to the fact that Village B experienced recurring ethnic conflicts since the 1980s to present (see Table 1).

Livestock ownership and diversity of income sources emerged with a significant relationship with households' seed (in)security vulnerability rating. Specifically, households owning livestock appeared to rate themselves as more seed secure compared to their counterparts without livestock. Also, households with multiple income sources, mostly additional income from off-farm activities, were less likely to report vulnerability to seed insecurity amid conflicts. This aligned with findings that outcomes of conflicts affect all dimensions of seed security by diminishing social capital, assets, and income to purchase seeds (FAO 2016). Hence, households with livestock and multiple income sources were less likely to deplete assets as a result of conflict outcomes.

The number of household members involved in agricultural activities was found to be statistically significant concerning households' seed insecurity vulnerability attributed to conflicts. The relationship 
Fig. 2 Households' seed (in)security rating Amid conflicts based on gender of household heads and village of location. a Gender of household heads (Pearson's chi-square test, $P=0.048$ ). b Village of location (Fisher's exact test, $P=0.000)$

Table 3 Households spatial and socioeconomic characteristics and seed security rating Source: Quantitative household surveys, July to August 2019
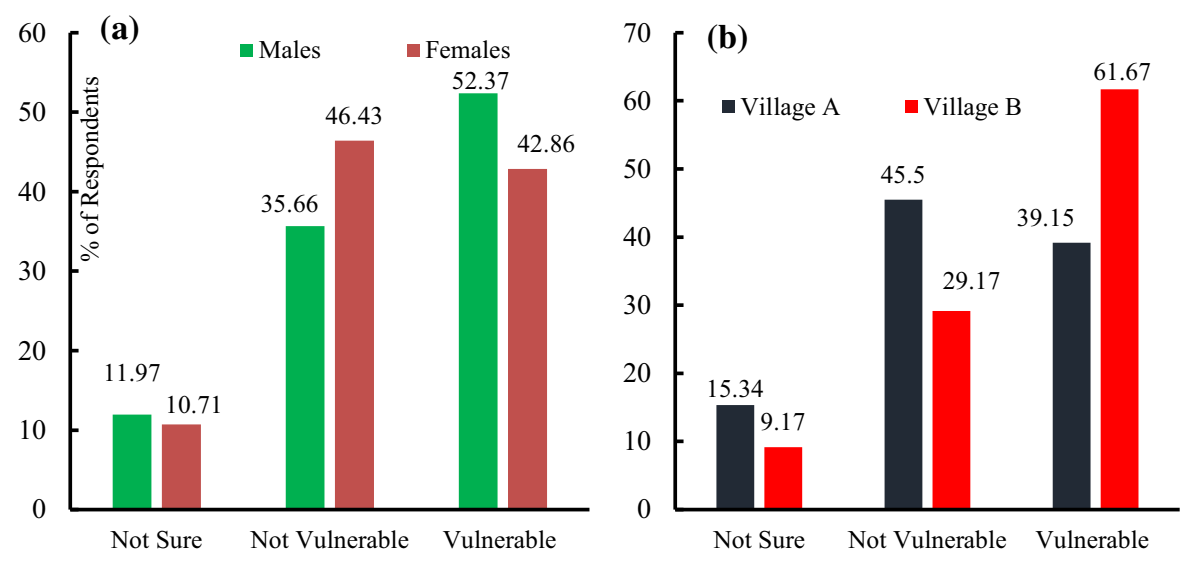

$* P<10 \%, * * P<5 \%$, $* * * P<1 \%$

\begin{tabular}{lrcc}
\hline Variable & df & $\chi^{2}$ (Cramer's V) & $P$ value \\
\hline 1. Location of respondent & 4 & $40.341(.307)^{* * *}$ & .000 \\
2. Age of the household head & 20 & $24.834(.357)$ & .208 \\
3. Education attainment & 20 & $24.146(.120)$ & .236 \\
4. Mobile phone ownership & 4 & $.104(.016)$ & .998 \\
5. Gender of the household head & 4 & $9.580(.149)^{* *}$ & .048 \\
6. Livestock ownership & 4 & $8.044(.137)^{*}$ & .090 \\
7. House size & 92 & $90.996(.231)$ & .510 \\
8. Number of household members in agriculture & 52 & $76.701(.211)^{* *}$ & .015 \\
9. Number of income sources & 24 & $34.303(.142)^{*}$ & .079 \\
10. Accessibility to credit and savings & 2 & $13.084(.167)^{* *}$ & .002 \\
11. Household's crop diversity & 44 & $56.276(.181)$ & .101 \\
12. The three major cultivated crops & 152 & $176.853(.321)^{*}$ & .082 \\
13. The method of farming & 6 & $20.092(.153)^{* * *}$ & .003 \\
14. Total annual income & 600 & $620.573(.601)$ & .272 \\
\hline
\end{tabular}

showed that households with some members engaged in off-farm activities rated themselves as more seed secure. This finding is due to the crucial role of nonfarm income and remittances during times of stress (see Sperling 2008). Among respondents, the average number of active working household members was 4.1, of which 2.9 were engaged in farming (Table 2), implying that in most of the sampled households at least one member was engaged in other incomeearning activities. Households with at least three members engaged in non-agricultural activities (mostly working in cities) were found to have a greater likelihood of seed security during conflict. Similarly, Antwi-Agyei et al. (2018) and Azumah et al. (2017) found that farmers who receive remittances from relatives tend to have greater resiliency to shocks because of financial support during stress. Intrinsically, these households can readily replenish lost seeds during shocks such as destruction by conflicts.

The households' seed security rating also significantly depended on the methods used by the farmers in preparing farmland. For instance, the higher-earning households were associated with the use of tractor plowing services and also rated themselves as less vulnerable to seed insecurity than those who used hand tools only. In-depth interactions with the farmers revealed that beyond having money to pay for the tractor service, it required establishing close relations (social network) with the tractor owners to ensure timely provision of service. Moreover, the method of land preparation by the individual farmers correlated 
with household's wealth $\left(\chi^{2}=160.333\right.$, Cramer's $\mathrm{V}=0.611)$. These results point to the increasing importance of power relations (social networks) and wealth in accessing desired seeds among smallholders (Assan et al. 2018; Coomes et al. 2015; Gaffney et al. 2016; Wencélius et al. 2016).

The results from the multinomial logistic regression parameters are presented in Table 4. The output indicates that out of all the variables in Table 3, the location of respondents, access to credit and savings, and the number of household members in agriculture are the significant predictors of households' seed security rating based on conflicts. The households in Village A have lower odds of rating themselves as vulnerable to seed insecurity due to conflicts compared to rating as not sure $(\mathrm{OR}=0.393, p<0.05)$. Thus, respondents in Village A were $60.7 \%$ (i.e., $[0.393-1] \%)$ less likely to rate themselves as vulnerable to seed insecurity compared to their counterparts in Village B. Moreover, households from Village A were associated with greater odds of rating themselves as not vulnerable to seed insecurity due to conflicts compared to being rated as not sure $(\mathrm{OR}=$ 2.360, $p<0.05)$. Respondents from Village-A were also associated with greater odds of rating themselves as not vulnerable to seed insecurity compared to being rated as vulnerable $(\mathrm{OR}=5.705, p<0.01)$. Overall, the farmers from Village-A were 4.705 times more likely to rate themselves as not vulnerable to seed insecurity compared to their counterparts in Village-B. Although the two villages are located in the same climatic zone, the differentiated vulnerability is largely attributed to the presence of protracted conflicts in Village-B (see Fig. 2b).

The households with more than three members engaged in agriculture were found to be associated with lower odds of been rated as vulnerable to seed insecurity due to conflicts compared to reporting as not sure $(\mathrm{OR}=0.738, p<0.05)$. Similarly, households with more than three members engaged in agriculture were $83.1 \%$ times less likely to rate themselves as not vulnerable to seed insecurity compared to their counterparts. This variable was not retained in the model when vulnerable to seed insecurity was made the reference category as the Wald ratio became insignificant.

For access to credit and savings, households without access were found to be more likely (OR = $3.340, p<0.01)$ to be vulnerable to seed insecurity relative to reporting as not sure. Thus, households without access were 2.340 times more likely to rate themselves as vulnerable to seed insecurity compared to those with access. On the other hand, households without access were associated with lower odds of rating themselves as not vulnerable to seed insecurity amidst conflicts compared to being rating as vulnerable ( $\mathrm{OR}=0.622, p<0.05)$. This means that households without access were $37.8 \%$ less likely to rate themselves as not vulnerable to seed insecurity compared to those with access.

Qualitative results of household vulnerability to seed insecurity

Interactions with households in the field through interviews and informal conversations revealed that politics (i.e., ethnic conflicts, land disputes, neoliberal and subsidized programs, and gender inequalities) affect smallholders' seed security in the NGS. The views and expressions of the farmers point to how both micro and macro-level politics undermine households' seed security in the study area. The following illustrations from fieldnotes show how politics and power imbalances disrupt seed security among smallholders. For example, one female respondent echoed this sentiment, saying:

I don't use the Agric maize [improved maize varieties]. How do I get those seeds, if not men that would go and purchase them, what would I go and say in the office? You know we women here. (42-year old female household head, July 2019).

This expression by a female household head is further buttressed by evidence that only $1.3 \%$ (14) and $3.6 \%$ (2) of female farmers in NNM accessed improved seeds in 2017 and 2018 respectively, although census reports indicated that $73.1 \%$ $(18,332)$ of the employed females are engaged in agriculture in NNM (Ghana Statistical Service 2014b). Table 2 provides details of the gender-differentiated access to improved seeds, showing how seed supply interventions developed without consideration of social and gendered differentiation could deepen inequalities in accessing desired seeds. Likewise, Galiè et al. (2017) noted that gender-blinded seed governance regimes at all levels have constrained 
Table 4 Multivariate determinants of households seed (in)security Amid conflicts

\begin{tabular}{|c|c|c|c|}
\hline \multicolumn{4}{|l|}{ Model parameter estimates } \\
\hline Independent variables & $\begin{array}{l}\text { Vulnerable to seed } \\
\text { insecurity }^{\text {a }} \\
\text { OR (SE) }\end{array}$ & $\begin{array}{l}\text { Not vulnerable to seed } \\
\text { insecurity } \\
\text { OR (SE) }\end{array}$ & $\begin{array}{l}\text { Not vulnerable to seed } \\
\text { insecurity } \\
\text { OR (SE) }\end{array}$ \\
\hline $\begin{array}{l}\text { Location of respondent } \\
\quad(\text { Ref. }=\text { Village A) }\end{array}$ & $0.393(0.356)^{* *}$ & $2.360(0.400)^{* *}$ & $5.705(0.404)^{* * *}$ \\
\hline $\begin{array}{l}\text { The number of household members } \\
\text { in agric. (Ref: } \#>3 \text { ) }\end{array}$ & $0.738(2191.200)^{*}$ & $0.187(2450.866)^{*}$ & - \\
\hline $\begin{array}{l}\text { Accessibility to credit and savings } \\
\quad(\text { Ref. }=\text { no access })\end{array}$ & $3.340(0.390)^{* * *}$ & $2.060(0.432)^{*}$ & $0.622(0.454)^{* *}$ \\
\hline Observations & 429 & 429 & 429 \\
\hline Model intercept & $(0.353)^{* *}$ & $(0.367)$ & $(0.394)^{* * *}$ \\
\hline Log Pseudo-likelihood $=\mathrm{X}^{2}(\mathrm{df})$ & $122.572(60)^{* * *}$ & $122.572(60)^{* * *}$ & $52.705(8)^{* * *}$ \\
\hline Deviance & 1.000 & 1.000 & 1.000 \\
\hline Cox and Snell & 0.251 & 0.251 & 0.117 \\
\hline Nagelkerke & 0.264 & 0.264 & 0.23 \\
\hline
\end{tabular}

OR, odds ratio, SE, standard error, $* P<10 \%, * * P<5 \%, * * * P<1 \%$, Ref:\#, reference category of the independent variable, $\chi^{2}$, chisquare statistic, $d f$, degree of freedom, $R^{2}$, regression coefficient. $a$, reference category is not sure of seed (in)security status. $b$, reference category is vulnerable to seed insecurity
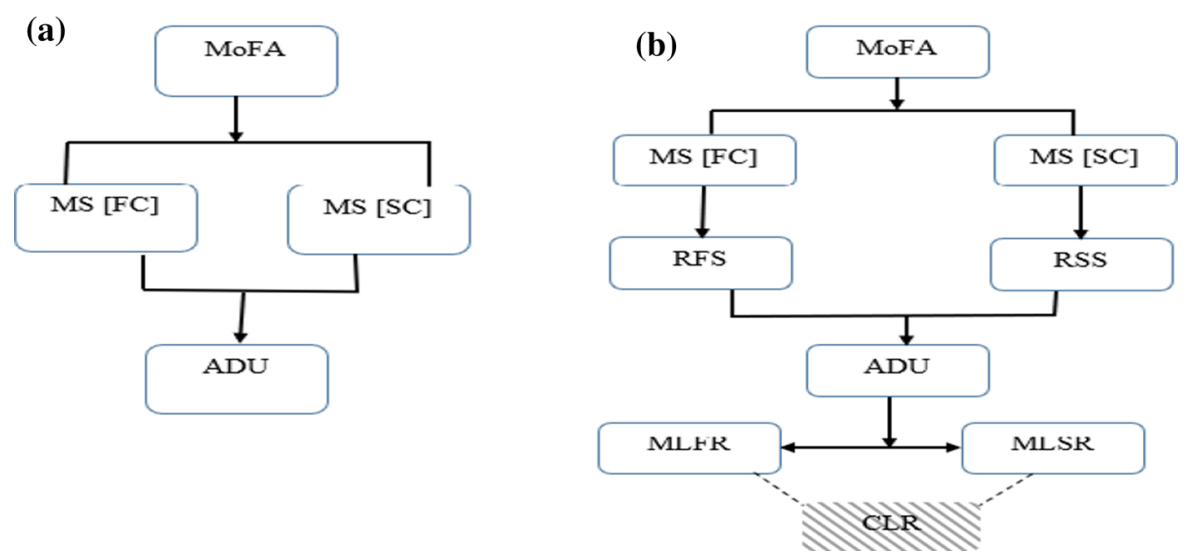

Fig. 3 Certified seeds supply chain organogram under the PF\&J program. The dashed region shows the nonexistence supply chain in the study villages. Source: Compiled from field interviews and notes, July to August 2019

equitable access among female farmers, which ultimately affects resiliency.

The government of Ghana has introduced policies to stimulate farmers to adopt certified seeds and expand their delivery to all farmers, often to increase agricultural productivity among smallholders. Recent in this regard is the PF\&J program, which aimed to make subsidized improved seeds available to all farmers across the country (MOFA 2017). However, my findings suggest that these efforts have not significantly ensured a sustainable supply of improved seeds to deprived farmers, especially in remote areas. Largely because of implementation challenges and poor understanding of the local context, which resulted in a situation where the farmers themselves are to be blamed for some of the problems with the program. As one of the key informants put it:

There're challenges with the PF\&J program implemented to provide subsidized fertilizer and 
improved seeds. I can't entirely blame the government officers and leave us [farmers]. See, we're told the initial intention was for us to access the package with half payment and make full payment later if we harvest our farm produce. However, some farmers failed to pay back after harvesting their produce. So, the officers now required a valid ID card before they would give us the package. And you know we use different ID cards in this country. In a particular year, one [farmer] can send a voter ID card, and another time he would send a different ID card. Even when it became clear that the officers would only accept voter ID cards, a farmer would send their voter ID for the claim, then the next year he would send his wife to use her own, all because they don't want to repay the government. (48-year old male household head, July 2019).

\section{Another stated}

We [farmers] are very challenged lately in getting adequate yields. So, what the current president did was that in 2017 he subsidized fertilizer together with improved seeds and made it available to us at the Municipal Agriculture Office. Even we were to pay half of the subsidized prices (i.e., $25 \%$ out of the $50 \%$ subsidies) and take the fertilizer with improved seeds and pay the remaining 25\% after harvest. Some of us weren't aware of it until the later part of the farming season. Some big [influential] people went to the office with as much as Gh $\phi 5,000$ and bought almost all. Out of the total purchase of the subsidized seeds, only $3.87 \%$ of the amount was recovered. I was told by the government Officer that they won't order any arrest or persecution of debtors. The reason being that when he goes after them [debtors], party leaders [politicians] will say he wants to cause the party['s] downfall. Consequently, all the subsidized seeds have been sent to commercial retailers. What is happening now is that if you've got the money you buy from the retailer shops or you go with a voter ID card to obtain a coupon from the office. Even with the coupon, the hustle we've to go through, so only a few in this community get to buy. (In-depth interview with a male household head, July 2019).

The above narratives from the farmers unravel the often-ignored nexus between the supply of improved seeds by policy interventions and the economic sustainability of those efforts. Similarly, Almekinders et al. (2019) indicated that the current approaches to supply improved seeds to smallholder farmers continue to favor decentralized multiplication modelswhich in many situations failed because of inadequate understanding of effective demand by farmers.

The initial modality for supplying subsidized seeds to farmers through $\mathrm{PF} \& \mathrm{~J}$ was to be done via the Agriculture Development Unit (ADU) at the District or Municipal offices (see Fig. 3a). Thus, the farmers were to acquire improved seeds at offices of the ADU within their locality. The PF\&J initial approach of delivering the improved seeds to farmers resulted in extra cost (i.e., cost of transport) among smallholders located in remote areas. Other earlier challenges revealed during the interviews included long queues of farmers at the ADU office and selling seeds in package sizes that do not meet the economic and farm size needs of the smallholder.

Ministry of Agriculture (MoFA), Main Suppliers (MS), Fertilizer Companies (FC), Seed Companies (SC), Regional Fertilizer Suppliers (RFS), Regional Seed Suppliers (RSS), Agriculture Development Unit (ADU), Municipal Level Fertilizer Retailers (MLFR), Municipal Level Seed Retailers (MLSR), Community Level Retailers (CLR).

The shortcomings of the earlier delivery modalities caused a significant change in the supply chain and packaging in the 2019 planting season (see Fig. 3b). The current supply organogram enables the farmers to purchase subsidized seeds in their communities at the same price nationwide through the CLRs. However, numerous communities in the NGS, including the study villages, still do not have CLRs and therefore resort to buying the seeds from the district or municipal capitals where MLSRs are located. The farmers in these remote areas still incur extra costs in accessing the seeds even after restructuring the program. This situation and others indicate that government seed policies continue to show evidence of the inability to adequately deliver improved seeds to the neediest farmers. 
Field interviews with the farmers also revealed that ramifications of macro-level policies, such as the implementation of ECOWAS free movement protocol, have also affected their seed security. The protocol granted the right to citizens within the subregion to enter, reside and establish economic activities in the territory of other member states to attain freedom of movement of persons after fifteen years of its enactment (Aduloju 2015). Therefore, periods proceeding fifteen years after its enactment in 1979 have witnessed unprecedented inflows of Fulani Herdsmen and their cattle from member states such as Benin, Mali, and Burkina Faso into the hinterlands of Ghana (see Akerlof 2017; Imoro 2018). The ultimate impacts of the increasing influx of the herdsmen have been reported by the farmers to include the destruction of saved seeds. One of the interviewed farmers described the situation, lamenting:

The presence of the Fulani cattle is a big worry to this community. Their cattle keep eating and destroying our farm produce including seeds stored on the farms. Do you see that brokendown house over there? That's my brother's house, but he left this village to Attebubu [in the forest belt] because of incessant destruction of his yam seeds by cattle, for which he never received compensation. (Interview with a household head, July 2019).

These destructions have also fueled several clashes and conflicts between the local crop farmers and the herdsmen (Akerlof 2017). Seed destruction by the cattle and clashes with the herdsmen are expected to increase in the future as climate change adversely impacts the availability of pasture in NGS. Besides, interactions with households on the field indicated that the intention to use some portions of the farmlands for teak plantation has been the main cause of the recent conflicts in Village-B. Most of the respondents repeatedly asserted that some 'big men' in the village want to take away their farmlands for personal gains. These purported individuals are said to be executing their intentions under the cover that the Municipal Assembly is undertaking an afforestation project to combat the effects of climate change in the area. But situations of this nature easily derail into clashes due to the anguish and distrust created by prolonged ethnic conflicts in the area since the 1980s. Talton (2003a) also noted that the individual farmers' disagreement occurring along ethnic divide in this area often resulted in conflicts (Fig. 4).

Although the afforestation effort seems to target only a few households' farmlands, the respondents insisted that they would not allow it to happen because they do not trust the process. For example, a respondent from one of the ethnic groups stated in a passionate tone that:

No, we won't allow it, after taking those farmlands they would come for ours too, and conflict will be inevitable. We've had similar experiences in this village. A whole lot of food [seeds] barns were burned down in the 1992-94 conflicts. We literally rely on relatives in other places for seeds (Interview with a household head, July 2019).

Another concern expressed among the respondents in Village-B includes the creation of a cemetery on the outskirts of the community. The establishment of the cemetery came with a bylaw enjoining all the ethnic groups in the village to bury their deceased persons in the cemetery except distinguished elderly members. However, the bylaw failed to clearly define who qualified as a distinguished elderly member. As a result, tensions along ethnic lines frequently erupt when any of the ethnic groups decide to honor a member by burying him/her within the community rather than in the cemetery. The destruction of household seeds reinforces itself amid the recurring conflicts-as victims of the destruction look for an opportunity to retaliate on suspected neighbors' saved seeds.

\section{Discussion}

Historically, government efforts to develop agriculture have been largely focused on the cash crop production regions in the south, to the neglect of NGS (Nyantakyi-frimpong and Bern-Kerr 2015; Plange 1979). Part of a later effort using a countrywide approach that included the NGS has focused on providing improved or certified seeds to farmers to increase productivity (Lyon and Afikorah-Danquah 1998; Tanko et al. 2019). However, Ghana's SAP and its conditionalities in 1983 resulted in the withdrawal of subsidies and support to farmers through government interventions (Shepherd et al. 2005). Besides, a 


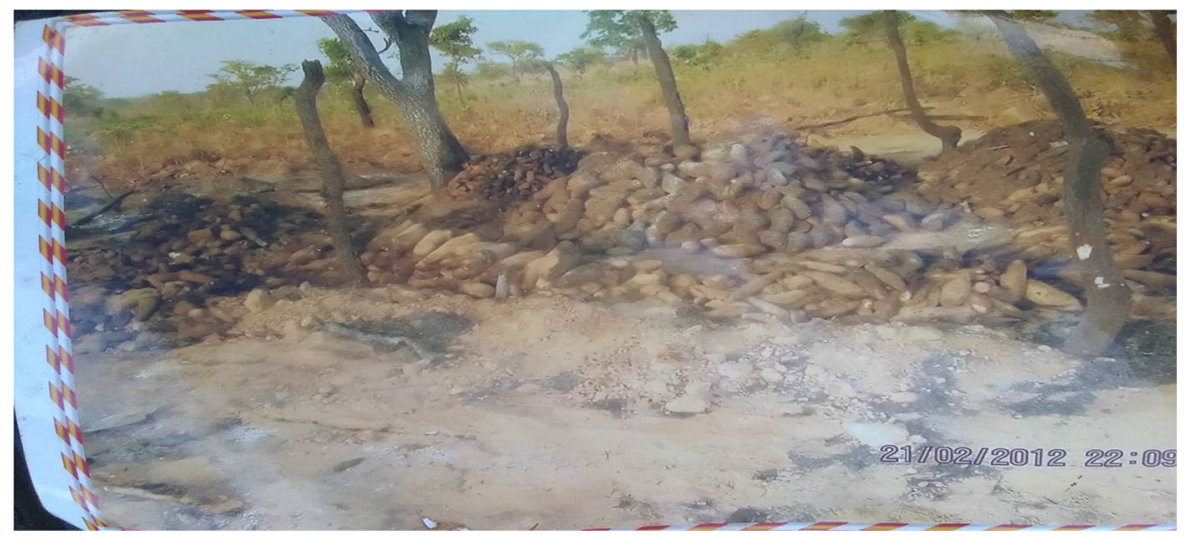

Fig. 4 A picture illustrating yam seeds destroyed by fire. A respondent pulled out this photo during an in-depth interview to show how his yam seeds were set on fire by other factions. Source: Fieldwork, August 2019

series of conflicts has engulfed almost all parts of NGS since the 1980s (Debrah et al. 2016; Talton 2003b), which are said to be a product of the postcolonial period and the political structure that the colonial officers imposed (Talton 2003a). The consequence of the conflicts includes the destruction of farmers' own saved seeds and social networks. Hence, whereas climate change serves as a major concern to farmers in the NGS, local and macro politics constitute a potential threat to smallholders' seed security. Using a political ecology approach, this paper examined the impact of historical, ethnic conflicts, political, and neoliberal economic policies on the smallholders' seed security in NGS.

The results showed that the location of the village and gender of the household heads significantly relates to how farmers rate their seed (in)security. This finding points to how micro-politics in the form of gender and intra-household differences mediate access to improved seeds in agrarian settings. Similarly, Nyantakyi-Frimpong and Bezner-Kerr (2015) found that gender politics and intra-household labor relations influenced the adoption of improved seeds in NGS. However, while Nyantakyi-Frimpong and BeznerKerr (2015) attributed this phenomenon to the disproportionated labor burden among gender, this study found cropping type and the geographical extent of seed acquisition as other possible explanatory factors. Thus, the major crop planted by male-headed households (i.e. yam) is prone to destruction during conflicts. The ability of males to travel outwards to acquire seeds are also often limited during conflicts due to curfews imposed by the government and fear of insecurity. Hence, respondents from a relatively peaceful village were associated with higher odds of rating themselves as not vulnerable to seed insecurity compared to being rated as vulnerable $(\mathrm{OR}=5.705$, $p<0.01)$. This result corroborates with earlier findings that conflicts pose a threat to seed security among farmers (see McGuire and Sperling 2013; Sperling 2008; Sperling et al. 2008) and call for critical research and policy consideration.

The analysis further suggests that households' seed security rating also significantly depends on access to credit and savings, a finding consistent with Assan et al. (2018); Gaffney et al. (2016); and Wencélius et al. (2016). Households with no access to credit had lower odds of rating themselves as not vulnerable to seed insecurity amidst conflicts compared to being rating as vulnerable $(\mathrm{OR}=0.622, p<0.05)$. Households with no access were $37.8 \%$ less likely to rate themselves as not vulnerable to seed insecurity compared to those with access. Yet, an earlier study showed that smallholder access to credit in the NGS has recently been firmly truncated by macro-level politics such as the SAP and privatization (KonaduAgyemang 2000). This has resulted in a situation where purchasing improved seeds is being promoted in a regime where the economic framework offers little support for the smallholders.

Besides the macropolitics, the empirical evidence unraveled the often-ignored nexus between improved seeds supply interventions and the economic sustainability of those efforts. Evident is the poor debt recovery (i.e., 3.87\%) and extra cost in acquiring improved seeds among farmers located in remote 
areas. Although the program has seen some restructuring, the farmers in the remote areas still face challenges accessing the seeds they need. These and other challenges indicate the inability to adequately deliver improved seeds to the neediest farmers. The finding adds more insight to earlier studies showing the flawed nature of most agricultural improvement initiatives (Carney and Carney 1993; Scoones and Thompson 2011). The results also revealed that the ramifications of neoliberal policies, such as the implementation of the ECOWAS free movement protocol, often disrupt the farmers' seed security. In this case, the influx of Fulani herdsmen and their cattle in the NGS, as a result of the enactment, intensified the destruction of saved seeds on farms.

\section{Conclusion}

Although earlier and critical studies in the sub-field of human-environment have explored how access and adoption of seeds among smallholders are shape by various factors. The approach and findings of this paper contribute significantly to research in this subfield. It contributes to these by demonstrating how historical ethnic conflicts, government seed programs, and neoliberal economic policies shape farmers' seed security. A novel contribution in this regard is the use of seed security assessment framework with consideration of all the seed systems (i.e., both formal and informal seed systems) available to the farmers, as well as analysis of both micro and macro politics. As the results demonstrate, it is not only climate change that might constrain and shape smallholder seed security, but also the local and macro-political economy.

Finally, this paper calls for further extension of seed security assessment to include broader contexts beyond the demography, wealth characteristics, and the ecological conditions of the farmers. It encourages government and non-governmental bodies providing improved seeds to pay attention to gender differences and locale, and get seed suppliers closer to the farmers. As the study results indicate, female-headed households were less likely to access improved seeds, and farmers in conflict-prone village were not able to acquire seeds outside during tensions. Moreover, for seed policies to meaningfully impact the smallholder, this paper calls for adequate understanding and the integration of political-economic conditions within which the farmers operate. It also recommends further research (e.g., ethnography) that allows for close, intimate familiarity, and intensive involvement in the farmers' cultural and political environment within which they operate, over an extended period.

Acknowledgements I thank God for this paper. I am grateful to all the faculty members in the Department of Geography and the Environment. My heartfelt thanks go to unanimous readers who proofread the draft and the editor and reviewers for the constructive comments. Also, my most sincere appreciation goes to the Field Research Assistants (i.e., Ms. Rehinatu Zakaria, Ms. Rashida Dramani, Mr. Abdul-Salam Jahanfo Abdulai, and Mr. Daniel Kwame Blija).

Funding This study received partial funding for the field trip to Ghana from Laurence C. Herold Fund for Student Field Research. Department of Geography and the Environment, University of Denver, CO USA. The funding sponsor has no role in the data collection, analysis and interpretation of data; in the writing of the paper; and in the decision to submit for publication.

\section{Compliance with ethical standards}

Conflict of interest The authors state that there are no conflicts of interest.

Ethical approval This study has received research ethics approval from the University of Denver [IRB Protocol \# 1428173-1].

\section{References}

Akerlof. (2017). Statement to parliament on the conflicts between the Fulani Herdsmen and Farming Communities in Ghana: any way forward? By honorable Alex AdomakoMensah, MP for Sekyere Afram plains. vol. 53. Accra, Ghana. http://www.odekro.org/Images/Uploads/

HonAlexAdomakoMensahontheconflictsbetween theFulaniherdsmenandfarmingcommunitiesin Ghana,Anywayforward.pdf.

Al-Hassan, R., \& Poulton, C. (2009). Agriculture and social protection in Ghana. Future agriculture consortium working paper SP04.

Alhassan, W., \& Bissi P. (2006). Program for Africa's seed systems (PASS). Ghana country report. Accra, Ghana: Rockefeller Foundation.

Almekinders, C. J. M., Walsh, S., Jacobsen, K. S., Andradepiedra, J. L., Mcewan, M. A., de Haan, S., \& Staver, C. (2019). Why interventions in the seed systems of roots, tubers, and bananas crops do not reach their full potential. Food Security, 11, 23-42.

Amuzu, A., Osei-Akoto, A., Anum, J., Mintah, S., Misefa, Y., Kusi-Boateng, A., Mensah, F. B. (2014). Ghana living 
standard survey round 6 (GLSS6). Poverty profile in Ghana (2005-2013). Accra-Ghana.

Antwi-Agyei, P., Dougill, A. J., Stringer, L. C., \& Codjoe, S. N. A. (2018). Adaptation opportunities and maladaptive outcomes in climate vulnerability hotspots of northern Ghana. Climate Risk Management, 19, 83-93. https://doi. org/10.1016/j.crm.2017.11.003.

Antwi-Agyei, P., Fraser, E. D. G., Dougill, A. J., Stringer, L. C., \& Simelton, E. (2012). Mapping the vulnerability of crop production to drought in Ghana using rainfall, yield, and socioeconomic data. Applied Geography, 32(2), 324-334. https://doi.org/10.1016/j.apgeog.2011.06.010.

Assan, E., Suvedi, M., Schmitt Olabisi, L., \& Allen, A. (2018). Coping with and adapting to climate change: A gender perspective from smallholder farming in Ghana. Environments, 5(8), $86 . \quad$ https://doi.org/10.3390/ environments5080086.

Asuming-Brempong, S. (1994). Effects of exchange rate liberalization and input-subsidy removal on the competitiveness of cereals in Ghana. In S. A. Barth (Ed.), Issues in African rural development (Vol. 2, pp. 43-59). Arlington, VA: Winrock International.

Asuming-Brempong, S. (2003). Economic and agricultural policy reforms and their effects on the role of agriculture in Ghana. Paper presented at the roles of agriculture international conference. October 2003, Rome, Italy.

Azumah, S. B., Donkoh, S. A., \& Ansah, I. G. K. (2017). Contract farming and the adoption of climate change coping and adaptation strategies in the northern region of Ghana. Environment, Development, and Sustainability, 19(6), 2275-2295. https://doi.org/10.1007/s10668-0169854-z.

Bockari-Kugbei, S.M. (1994). The role of small-scale enterprises in African seed industries. Doctor of philosophy thesis, department of agricultural economics, university of reading, $\mathrm{UK}$.

Botchway, K. (2001). The paradox of empowerment: Reflections on a case study from Northern Ghana. World Development, 29(1), 135-153. https://doi.org/10.1016/S0305$750 \mathrm{X}(00) 00084-\mathrm{X}$.

Byerlee, D., \& Bernstein, J. (2013). Feed the Future Learning Agenda Literature Review: Improving Research and Development. Rockville, MD: Westat. Retrieved from https://pdf.usaid.gov/pdf_docs/PA00KMC7.pdf

CARE International. (2013). Adaptation Learning Programme ( ALP ) climate change vulnerability and adaptive capacity in Northern Ghana. Accra, CARE International, and ALP Ghana project. https://careclimatechange.org/wp-content/ uploads/2014/08/CVCA_Ghana.pdf

Carney, J., \& Carney, J. (1993). Converting the Wetlands, engendering the environment: the intersection of gender with agrarian change in the Gambia. Economic Geography, 69, 329-348.

Chamberlin, J. (2007). Defining smallholder agriculture in Ghana: Who are smallholders, what do they do and how are they linked with markets? [(IFPRI) Background paper No. GSSP 0006]. Washington, DC.

Coomes, O. T., McGuire, S. J., Garine, E., Caillon, S., McKey, D., Demeulenaere, E., \& Wencélius, J. (2015). Farmer seed networks make a limited contribution to agriculture. Four common misconceptions. Food Policy, 56, 41-50. https:// doi.org/10.1016/j.foodpol.2015.07.008.

Creswell, J. W., \& Plano Clark, V. L. (2017). Designing and conducting mixed methods research (2nd ed.). Los Angeles, Califonia: SAGE Publications.

Debrah, E., Alidu, S., \& Owusu-Mensah, I. (2016). Journal of African conflicts and peace studies the cost of inter-ethnic conflicts in Ghana's Northern Region: the case of the Nawuri-Gonja conflicts. Journal of African Conflicts and Peace Studies. https://doi.org/10.5038/2325-484X.3.1. 1068.

Delimini, L.L., Wobil, J. (1998) Ghana seed sector analysis. Report prepared for the IITA/GTZ project on the promotion of seed production and marketing in West Africa.

Development Initiatives. (2020). 2020 Global nutrition report: action on equity to end malnutrition. The Global Nutrition Report's Independent Expert Group. Bristol, UK. https:// doi.org/10.2499/9780896295841.

FAO (1998) Developing seed security strategies and programs for food security in developing countries, in Proceedings of the international workshop on seed security for food security, 30 November-1.

FAO (2005) FAO's initiatives for capacity building to support the utilization of plant genetic resources for food and agriculture through seed systems and plant breeding and genetic enhancement. Commission on plant genetic resources for food and agriculture, working group on plant genetic resources for food and agriculture third session, Rome 26-28 2005 CGRFA/WG-PGR 3/05/04, FAO, Rome, Italy.

FAO. (2010). Seeds in emergencies: A technical handbook. FAO plant production and protection paper vol. 202. Rome, the United Nations: Seed and Plant Genetic Resources Group of the Plant Production and Protection Division (AGPMG) in collaboration with the Emergency Operations and Rehabilitation Division (TCE).

FAO. (2015). Building capacity for seed security assessments. Seed security assessment-A practitioner's guide. (1). Rome, Italy. http://www.fao.org/3/a-i5548e.pdf.

FAO. (2016). Seed security assessment-A practitioner's guide. Rome, Italy. http://www.fao.org/3/a-i5548e.pdf.

FAO, IFAD, UNICEF, WFP, and WHO. (2019). The state of food security and nutrition in the world 2019. Safeguarding against economic slowdowns and downturns. Rome, Italy. https://docs.wfp.org/api/documents/WFP-0000106760/ download/?_ga=2.258667082.1791989143.15912821681557303673.1591282168 .

Field, A. (2013). Discovering statistics using IBM SPSS statistics. (I. Carmichael, Michael; Lupton, Robin; Antclif, Ed.) (4th ed.). Thousand Oaks, California: SAGE Publications Inc.

Gaffney, J., Anderson, J., Franks, C., Collinson, S., MacRobert, J., Woldemariam, W., \& Albertsen, M. (2016). Robust seed systems, emerging technologies, and hybrid crops for Africa. Global Food Security, 9, 36-44. https://doi.org/10. 1016/j.gfs.2016.06.001.

Galiè, A., Jiggins, J., Struik, P. C., Grando, S., \& Ceccarelli, S. (2017). Women's empowerment through seed improvement and seed governance: Evidence from participatory barley breeding in pre-war Syria. NJAS Wageningen 
Journal of Life Sciences, 81, 1-8. https://doi.org/10.1016/j. njas.2017.01.002.

Ghana Statistical Service. (2012). 2010 population and housing census summary report of the final results for the regions. Accra, Ghana.

Ghana Statistical Service. (2014a). 2010 population and housing census: District analytical report; East Gonja District. Ghana, Accra. https://www2.statsghana.gov.gh/docfiles/ 2010_District_Report/Northern/East\%20Gonja.pdf

Ghana Statistical Service. (2014b). 2010 population and housing census: District analytical report; Nanumba North District. Accra, Ghana Statistical Service. www.statsghana.gov.gh.

Ghana Statistical Service. (2014c). Ghana living standards survey round 6. Main report. Ecosystems and human wellbeing: A framework for assessment (vol. 12). https://doi. org/10.1007/s13398-014-0173-7.2.

Hilton, T. E. (1959). Land planning and resettlement in Northern Ghana. Geography, 44(4), 227-240.

Hopkins, D. R., Ruiz-Tiben, E., Downs, P., Withers, P. C., \& Maguire, J. H. (2005). Dracunculiasis eradication: The final inch. American Journal of Tropical Medicine and Hygiene, 73(4), 669-675. https://doi.org/10.4269/ajtmh. 2005.73.669.

Imoro, M. (2018). The Fulani Herdsmen Crisis in West Africa: The case of Agogo area in the Asante-Akim North district, Ashanti region of Ghana. University of Ghana, Legon.

Internal Displacement Monitoring Center. (2019). Ghana: Figure analysis-displacement related to conflict and violence. Accra, Ghana. https://www.internal-displacement. org/countries/ghana.

Jain, M., Naeem, S., Orlove, B., Modi, V., \& Defries, R. S. (2015). Understanding the causes and consequences of differential decision-making in adaptation research: Adapting to a delayed monsoon onset in Gujarat, India. Global Environmental Change, 31, 98-109. https://doi. org/10.1016/j.gloenvcha.2014.12.008.

Kansiime, M. K., \& Mastenbroek, A. (2016). Enhancing resilience of farmer seed system to climate-induced stresses: Insights from a case study in the West Nile region, Uganda. Journal of Rural Studies, 47, 220-230. https://doi.org/10. 1016/j.jrurstud.2016.08.004.

Konadu-Agyemang, K. (2000). The best of times and the worst of times: Structural adjustment programs and uneven development in Africa: The case of Ghana. Professional Geographer, 52(3), 469-483. https://doi.org/10.1111/ 0033-0124.00239.

Lyon, F., \& Afikorah-Danquah, S. (1998). Small-scale seed provision in Ghana: Social relations. Contracts and Institutions for Micro-Enterprise Development, 84, 1-16.

Mahama, E. S., \& Longi, F. T. (2013). Conflicts in Northern Ghana: Search for solutions, stakeholders, and way forward. GJDS, 10(1), 112-129.

McGuire, S., \& Sperling, L. (2011). The links between food security and seed security: Facts and fiction that guide response. Development in Practice, 21(4-5), 493-508. https://doi.org/10.1080/09614524.2011.562485.

McGuire, S., \& Sperling, L. (2013). Making seed systems more resilient to stress. Global Environmental Change, 23(3), 644-653. https://doi.org/10.1016/j.gloenvcha.2013.02. 001.
McGuire, S., \& Sperling, L. (2015). Seed systems smallholder farmers use. Food Security, 8, 1-36.

Michalscheck, M., Groot, J. C. J., Kotu, B., Hoeschle-Zeledon, I., Kuivanen, K., Descheemaeker, K., \& Tittonell, P. (2018). Model results versus farmer realities. Operationalizing diversity within and among smallholder farm systems for a nuanced impact assessment of technology packages. Agricultural Systems, 162, 164-178. https://doi. org/10.1016/j.agsy.2018.01.028.

Miles, M. B., Huberman, M., \& Saldana, J. (2014). Qualitative data analysis: A methods sourcebook. Thousand Oaks: SAGE.

MOFA. (2017). Ministry of Food and Agriculture, Ghana. Agricultural sector progress report 2017. http://mofa.gov. gh/site/wppontent/uploads/2018/09/MoFA\%202017\% 20AGRICULTURAL\%20PROGRESS\%20REPORT_ Final.PPMED.MoFA.pdf.

Mohammed, T., Ismaila, S., \& Sadiq, S. A. (2019). Planting for food and jobs (PFJ): A panacea for productivity and welfare of rice farmers in planting for food and jobs (PFJ): A panacea for productivity and welfare of rice farmers in Northern Ghana. Cogent Economics and Finance, 7, 1693121. https://doi.org/10.1080/23322039.2019. 1693121.

Mucioki, M., Hickey, G. M., Muhammad, L., \& Johns, T. (2016). Supporting farmer participation in formal seed systems: Lessons from Tharaka Kenya. Development in Practice, 26(2), 137-148. https://doi.org/10.1080/ 09614524.2016.1131812.

Mucioki, M., Pelletier, B., Johns, T., Muhammad, L. W., \& Hickey, G. M. (2018). On developing a scale to measure chronic household seed insecurity in semi-arid Kenya and the implications for food security policy. Food Security, 10(3), 571-587. https://doi.org/10.1007/s12571-018-08072.

Musah-Surugu, I. J., Bawole, J. N., \& Ahenkan, A. (2018). the "third sector" and climate change adaptation governance in Sub-Saharan Africa: Experience from Ghana. VOLUNTAS: International Journal of Voluntary and Nonprofit Organizations. https://doi.org/10.1007/s11266-018-99625.

Nyadzi, E., Nyamekye, A. B., Werners, S. E., Biesbroek, R. G., Dewulf, A., Slobbe, E. V., \& Ludwig, F. (2018). Diagnosing the potential of hydro-climatic information services to support rice farming in northern Ghana. NJAS Wageningen Journal of Life Sciences. https://doi.org/10. 1016/j.njas.2018.07.002.

Nyantakyi-frimpong, H., \& Bezner-kerr, R. (2015). The relative importance of climate change in the context of multiple stressors in semi-arid Ghana. Global Environmental Change, 32, 40-56. https://doi.org/10.1016/j.gloenvcha. 2015.03.003.

Nyantakyi-frimpong, H., \& Kerr, R. B. (2015). A political ecology of high-input agriculture in Northern Ghana. African Geographical Review, 6812, 1-23. https://doi.org/ 10.1080/19376812.2014.929971.

Opanike, A., \& Aduloju, A. A. (2015). ECOWAS protocol on free movement and trans-border security in West Africa. Journal of Civil Legal Science, 4, 154. https://doi.org/10. 4172/2169-0170.1000154. 
Patton, M. Q. (2014). Qualitative research and evaluation, ethods: Integrating theory and practice (4th ed.). Thousand Oaks, CA: SAGE.

Plange, N.-K. (1979). Under development in Northern Ghana: Natural causes or colonial capitalism? Linked references are available on JSTOR for this article: Underdevelopment in Norther Ghan: Natural causes or colonial capitalism? Review of African Political Economy, 6(15-16), 4-14.

Pul, H. (2004). Exclusion, Association and violence: Trends and triggers in Northern Ghana's Konkomba-Dagomba wars. Occasionnal Paper/Article Ponctue, https://doi.org/10. 4314/aa.v10i1.46099.

Ricciardi, V. (2015). Social seed networks: Identifying central farmers for equitable seed access. Agricultural Systems, 139, 110-121.

Robbins, P. (2012). Political ecology: A critical introductions to geography. (J. P. Jones III, ed.) (2nd ed). Malden, MA, USA: Blackwell Publishing Ltd.

Rock, J. (2019). "We are not starving:” challenging genetically modified seeds and development in Ghana. Culture Agriculture Food and Environment, 41(1), 15-23. https://doi. org/10.1111/cuag.12147.

Samberg, L. H., Shennan, C., \& Zavaleta, E. (2013). Farmer seed exchange and crop diversity in a changing agricultural landscape in the Southern Highlands of Ethiopia. Human Ecology, 41(3), 477-485. https://doi.org/10.1007/s10745013-9579-7.

Scoones, I., \& Thompson, J. (2011). The politics of seed in Africa's green revolution: Alternative narratives and competing pathways. IDS Bulletin, 42(4), 1-23. https://doi. org/10.1111/j.1759-5436.2011.00232.x.

Seini, A. W., \& Nyanteng, V. K. (2003). Afrint macro study: Ghana report (revised). Legon-Accra: Institute of Statistical, Social, and Economic Research (ISSER). The University of Ghana, September.

Sekhar Bahinipati, C., \& Venkatachalam, L. (2015). What drives farmers to adopt farm-level adaptation practices to climate extremes: Empirical evidence from Odisha, India. International Journal of Disaster Risk Reduction, 14, 347-356. https://doi.org/10.1016/j.ijdrr.2015.08.010.

Shepherd, A., C. Jebuni, R. Al-Hassan, A. McKay, C. Poulton, A. W., and J. K. (2005). Economic growth in Northern Ghana. Revised report prepared for DFID Ghana. Terra (vol. 109). London, UK/Accra, Ghana.

Shiva, V., Emani, A., \& Jafri, A. H. (1999). Globalization and threat to seed security. Economic and Political Weekly, 34(10/11), 601-613.

Sperling, L. (2008). When disaster strikes: A guide to assessing SSS. Cali, Colombia: International Center for Tropical Agriculture. www.ciat.cgiar.org/africa/seed.htm.

Sperling, L., Cooper, H. D., \& Remington, T. (2008). Moving towards more effective seed aid. Journal of Development Studies, 44(4), 586-612. https://doi.org/10.1080/ 00220380801980954.

SRID (2016). Agriculture in Ghana. Facts and figures (2016) Ministry of food and agriculture-statistics, research and information directorate (srid) October 2017.
The Wall Street Journal (2016). Bill Gates: GMOs will end starvation in Africa. Uploaded January 22. Video, 3:15 min. https://www.wsj.com/video/bill-gates-gmos-willend-starvation-in-africa/3085A8D1-BB58-4CAA-9394E567033434A4.html. Accessed 25 Jun 2020.

Talton, B. A. (2003a). The past and present in Ghana's Ethnic conflicts: British colonial policy and Konkomba Agency, 1930-1951. Journal of Asian and African Studies, 38, 192-210. https://doi.org/10.1093/abbs/gmr026.

Talton, B. A. (2003b). The past and present in Ghana's Ethnic conflicts: British Colonial Policy and Konkomba Agency 1930-1951. Journal of Asian and African Studies, 38, 192-210. https://doi.org/10.1093/abbs/gmr026.

Talton, B. A. (2010). Politics of social change in Ghana: The Konkomba struggle for political equality (1st ed.). New York, NY 10010: Palgrave Macmillan ${ }^{\circledR}$. https://doi.org/10. 1057/9780230102330.

Taylor, M. J. (2007). Militarism and the environment in Guatemala. GeoJournal, 69(3), 181-198. https://doi.org/10. 1007/s10708-007-9108-6.

Tonah, S. (2012). the politicization of a chieftaincy conflict: The case of Dagbon, Northern Ghana. Nordic Journal of African Studies, 21(1), 1-20.

Tripp, R., \& Mensah-bonsu, A. (2013). Ghana commercial seed sector. New incentive or continue complacency. International Food Policy Research Institute, April.

Violon, C., Thomas, M., \& Garine, E. (2016). Good year, bad year: Changing strategies, changing networks? A two-year study on seed acquisition in northern Cameroon. Ecology and Society, https://doi.org/10.5751/ES-08376-210234

Waldman, K. B., Blekking, J. P., Attari, S. Z., \& Evans, T. P. (2017). Maize seed choice and perceptions of climate variability among smallholder farmers. Global Environmental Change, 47(April), 51-63. https://doi.org/10.1016/ j.gloenvcha.2017.09.007.

Wattnem, T. (2016). Seed laws, certification, and standardization: outlawing informal seed systems in the Global South. The Journal of Peasant Studies, 43(4), 850-867. https:// doi.org/10.1080/03066150.2015.1130702.

Wencélius, J., Thomas, M., Barbillon, P., \& Garine, E. (2016). Interhousehold variability and its effects on seed circulation networks: A case study from northern Cameroon. Ecology and Society. https://doi.org/10.5751/ES-08208210144.

Yaro, J. A., Teye, J., \& Bawakyillenuo, S. (2015). Local institutions and adaptive capacity to climate change/variability in the northern savannah of Ghana. Climate and Development, 7(3), 235-245. https://doi.org/10.1080/17565529. 2014.951018.

Publisher's Note Springer Nature remains neutral with regard to jurisdictional claims in published maps and institutional affiliations. 